Aleksandra Porjazoska Kujundziski ${ }^{1 *}$ Dragica Chamovska ${ }^{2}$

${ }^{1}$ International Balkan University, Faculty of Engineering, Skopje, R. Macedonia, ${ }^{2}$ Ss. Cyril and Methodius University, Faculty of Technology and Metallurgy, Skopje, R. Macedonia
Review paper

ISSN 0351-9465, E-ISSN 2466-2585

UDC:678.06.615.4

doi: $10.5937 /$ ZasMat1703333P

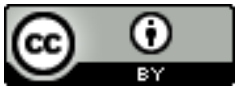

Zastita Materijala 58 (3)

333 - $348(2017)$

\title{
Biodegradable polymers suitable for tissue engineering and drug delivery systems
}

\begin{abstract}
Biodegradable polymers for medical and pharmaceutical application have been in the focus of scientific interest in the last two decades. Among the others, features like biocompatibility, supportive cell proliferation and biodegradation are considered as crucial in the fabrication of scaffolds in tissue engineering and controlled drug delivery systems. Polymers based on polyesters, polyethers, polyanhydrides, poly(ether esters), poly(ortho esters), poly(amino acids) are very significant for the application in medicine and pharmaceutics. Porous polymer matrices in tissue engineering encourage the growth of cells, at the same time allowing the exchange of nutrients and residuals. Drug delivery systems, where biological agent is dispersed / dissolved in the polymer matrix, act as reservoirs, while drug carriers are those systems where the active substance and matrix are chemically bonded. Of particular interest to many researchers are the systems in which degradation profile of polymer matrix is crucial in the determination of the rate by which the medicament is released. Biodegradable nanosized systems as devices of controlled release or selected targeting of active component attract significant attention.

This paper provides a brief outline of biodegradable polymers, the properties important for their application in medicine, with particular interest in their hydrolytic degradation, and at the same time, it will serve as a basis for further research in this area.
\end{abstract}

Keywords: biodegradable polymers, tissue engineering, drug delivery systems.

\section{INTRODUCTION}

In accordance to their application in medicine, biomaterials have been classified mainly into three groups: (1) materials for load bearing applications supporting high stresses, (2) tissue engineering scaffold and (3) drug delivery systems. On the other hand, with regards to their behaviour in biological systems, biomaterials could be categorized as: biocompatible, bioinert, biodegradable and bioactive materials. Generally, metals, ceramics, ceramics-based composites and polymers have been considered as the most suitable materials for medical application [1, 2].

Features like biocompatibility, shaping into different forms, cell adhesion, cell proliferation and cell differentiation support, ability to mimic the microenvironment of the natural tissues, allowing at the same time diffusion of nutrients and residuals, have made both, natural and synthetic polymers, very attractive materials in tissues regeneration applications [3].

\footnotetext{
${ }^{*}$ Corresponding author: A. Porjazoska Kujundziski

E-mail: aporjazoska@ibu.edu.mk

Paper received: 15. 06. 2017.

Paper accepted: 10. 07. 2017.

Paper is available on the website: www.idk.org.rs/journal
}

Natural polymers based on collagen have been the first type of the surgical materials used by Egyptians 3500 BC. Polymers of natural origin such as alginate, collagen, chitosan, hyaluronic acid and their derivatives have been the most exploited materials suitable for tissue engineering scaffolds and drug delivery systems fabrication [410]. On the other hand, in the last several decades, natural polymers have been replaced by synthetic ones, particularly in the applications such as sutures, materials for regeneration/replacement of diseased or damaged tissues and/or drug reservoir systems with local therapeutic effect [8, 9]. Continuous development of polymer science and technology, and application of different techniques in terms of preparation of polymer mixtures and blends has resulted in generation of variety of polymer materials ensuring appropriate features required in specific applications.

Thus, bone fixation devices have been fabricated by polymers of high strengths, while polymers forming soft membranes or films have been suitable in the places where prevention of adhesion is necessary. Polymers supporting big stresses have been practiced in skin remediation. Besides their mechanical characteristics, properties like surface morphology, as well as the ability of polymers to be degraded into low molecular mass 
species, play significant role in biomedical applications [10, 11].

The problems issued by permanent implants have been mainly related to physical irritation, inflammation, failure in adaptation to the tissue growth, corrosion, accumulation of metals in the human body, as well as repetitive surgical treatments. In addition to these, stress shielding is also a disadvantage of non-degradable implants. It has been also noticed that rehabilitated bone cannot be exposed to sufficient stresses during healing resulting in reoccurrence of bone fracture after inserts removal. The significance of biodegradable polymers in biomedical application lies in their ability for hydrolytic and / or enzymatic degradation. After fulfilling their function, biodegradable implants degrade to low molecular mass metabolites, avoiding the second surgical intervention. This pheno- menon ensures decrease in total recovery expenses. At the same time, as biodegradable inserts deteriorate, the stresses imposed during healing progressively transfer to the bone $[8,12]$. The other potential areas of application of degradable polymers are systems of controlled medicament release. Thus, in the abovementioned orthopaedic applications, controlled drug delivery systems (CDSS) can be also included, providing a certain dosage of morphogenic proteins that enhance fracture recuperation. Alternatively, CDSS supplying recovery bone tissues by certain amount of antibiotics prevent the occurrence of side effects such as osteomyelitis [13].

Different biodegradable polymer materials for medical applications have been developed, Table 1 , but the most significant are those based on lactic and glycolic acids [3].

Table 1. Representatives of synthetic biodegradable polymers used or tested for medical application

Tabela 1. Nekoliko predstavnika sintetičkih biodegradabilnih polimera koji se koriste ili testiraju u medicinske svrhe

\begin{tabular}{|c|c|c|c|}
\hline Polymer & Structure & Degradation rate & Application in medicine \\
\hline \multicolumn{4}{|l|}{ Polyesters } \\
\hline Poly(glycolic acid) (PGA) & Semi-crystalline & $\begin{array}{c}100 \% \\
(4-6 \text { months })\end{array}$ & $\begin{array}{l}\text { Sutures }\left(\text { Dexon }^{\circledR}\right) \text {, fracture fixation [3], } \\
\text { scaffolds for cartilage and blood vessels } \\
\text { regeneration [10] }\end{array}$ \\
\hline Poly(L-lactic acid) (PLLA) & Semi-crystalline & $\begin{array}{c}100 \% \\
>2 \text { years } \\
\end{array}$ & $\begin{array}{l}\text { Sutures, fracture fixation, regeneration of } \\
\text { bones [3], cartilage and nerves [10] }\end{array}$ \\
\hline Poly(DL-lactic acid) (PDLLA) & Amorphous & $\begin{array}{c}100 \% \\
(12-16 \text { months })\end{array}$ & Cartilage regeneration [3], CDDS* [14], \\
\hline $\begin{array}{l}\text { Poly(glycolic acid-co-L- lactic acid) } \\
(15 / 85 ; 25 / 75 ; 35 / 65 ; 50 / 50)\end{array}$ & Amorphous & $\begin{array}{c}100 \% \\
(1-6 \text { months })\end{array}$ & $\begin{array}{l}\text { Sutures, fracture fixation [3, bone, cartilage, } \\
\text { skin [14], blood vessels, nerves, liver, CDDS } \\
{[3]}\end{array}$ \\
\hline Poly(ع-caprolactone) & Semi-crystalline & $\begin{aligned} & 100 \% \\
&> 2 \text { years } \\
&\end{aligned}$ & $\begin{array}{l}\text { Sutures }\left(\text { Monocryl }{ }^{\circledR}\right) \text { [3; bone and cartilage } \\
\text { regeneration [10], CDDS for contraception [3] }\end{array}$ \\
\hline \multicolumn{4}{|l|}{ Polyethers } \\
\hline $\begin{array}{l}\text { Poly(ethylene glycol) / Po- } \\
\text { ly(ethylene oxide) }\end{array}$ & Semi-crystalline & l & $\begin{array}{l}\text { Hydrogel for cartilage regeneration, PLA-PEO } \\
\text { nanoparticles and hydrogel for CDDS } \\
\text { Polyactive }^{\star \star} \text { - for skin regeneration }[10,14]\end{array}$ \\
\hline Polyanhydrides & l & $\begin{array}{c}100 \% \\
\text { from several days up to } \\
\text { several years } \\
\end{array}$ & $\begin{array}{l}\text { Scaffolds for bone regeneration, CDDS } \\
\left(\text { Gliadel }^{\circledR} \text { ) (insulin, growth factors, inhibitors, }\right. \\
\text { enzymes) [3] }\end{array}$ \\
\hline \multicolumn{4}{|l|}{ Poly(ether esters) } \\
\hline Polydioxanone & Semi-crystalline & $\begin{array}{c}100 \% \\
(30 \text { weeks) }\end{array}$ & $\begin{array}{l}\text { Sutures }\left(\mathrm{PDS}^{\circledR}\right) \text {; fracture fixation [3], regene- } \\
\text { ration of cartilage and blood vessels [10] }\end{array}$ \\
\hline Poly(orthoesters) & Amorphous & $\begin{array}{c}60 \% \\
(50 \text { weeks }) \\
\end{array}$ & $\begin{array}{l}\text { Scaffolds for bone regeneration, CDDS for } \\
\text { contraception [3] }\end{array}$ \\
\hline Poly(amino acids) & Semi-crystalline & $\begin{array}{c}\text { Depending on the } \\
\text { hydrophilicity of amino } \\
\text { acid }\end{array}$ & $\begin{array}{l}\text { CDDS for low molecular mass drugs, for drugs } \\
\text { attached to the polymer with covalent bond [3] }\end{array}$ \\
\hline "Pseudo"-poly(amino acids) & Semi-crystalline & $\begin{array}{c}100 \% \\
>2 \text { years } \\
\end{array}$ & Fracture fixation [10] \\
\hline Polyurethanes & 1 & 1 & Scaffolds for blood vessels regeneration [3] \\
\hline $\begin{array}{l}\text { Polyphosphazenes - } \\
\text { - with amino end-groups }\end{array}$ & l & $\begin{array}{c}\text { Depending on the } \\
\text { hydrophilicity of amino } \\
\text { acid }\end{array}$ & $\begin{array}{l}\text { Bones and nerves regeneration, CDDS for } \\
\text { anti-inflammatory agents and peptides [3] }\end{array}$ \\
\hline
\end{tabular}


Poly(glycolic acid) PGA is recognized as a rigid highly crystalline polymer (45-55\%), whose melting point depending on molar mass values ranges between 225 and $230{ }^{\circ} \mathrm{C}$, while its glass transition temperature varies between 35 and $40 \stackrel{\circ}{\circ}$. Properties like high strength $(60-100 \mathrm{MPa})$, module of elasticity ( $6-7 \mathrm{GPa})$ and large rigidity (elongation at break $1.5-20 \%$ ) restrict areas of PGA application [18]. PGA sutures experience loss of their strength of around $50 \%$ in two weeks; in a period of 4 weeks they deteriorate almost $100 \%$; and they are completely absorbed in about 6 months [16].

Poly(L-lactic acid) (PLLA) is a semi-crystalline polymer with about $37 \%$ crystallinity, melting point $175-178 \stackrel{\circ}{\circ}$ and glass transition temperature between 55 and $60{ }^{\circ} \mathrm{C}$ [19]. Variations in melting point and crystallinity values have been observed in polymers of different lengths, i.e. different molar masses, as well as in polymers of diverse processing history [18]. Great percentage of crystalline regions has been observed in PLLA materials of high purity $\sim 73-75 \%$. Features like large yield (50 - $70 \mathrm{MPa})$ and bending (100 MPa) strengths, modulus of elasticity ( $3-4 \mathrm{GPa})$ and small ductility $(4 \%)$ indicate suitability of PLLA for sutures, bone fixations and other high stresses applications [1921]. As far as stability of PLLA in biological media is concerned, it was noticed that more than 2 years are required for its total degradation to small metabolites [15].

Poly(DL-lactic acid) (PDLLA) is an amorphous polymer consisting of two isomeric forms of lactic acid, L- and DL-, statistically distributed throughout the chain. Compared to PLLA, poly(DL-lactic acid) is characterized by smaller yield strength $(30-50$ $\mathrm{MPa}$ ), bigger ductility (up to $10 \%$ ), and considerably pronounced degradation. Preparation of PDLLA by copolymerization of DL-lactic and L-lactic acids results in disturbance of crystallinity regions in pure PLLA, and thus in a smaller period of time of polymer degradation [15].

Great changes in polymer properties occur by copolymerization of lactic and glycolic acids [1, 10, 14]. Appropriate amorphous or crystalline structures of copolymers have been obtained using different ratios of lactic and glycolic acid in the polymerization system. It was observed [10] that poly (DL-lactic acid - co - glycolic acid) (PDLLGA) containing between 0 and $70 \%$ glycolic acid has established amorphous structure, while crystalline copolymer of L-lactic and glycolic acid contains 25 - $70 \%$ glycolic acid [10]. Poly(lactic acid - co glycolic acid) has been considered as a suitable material in orthopaedic fixation [22], as tissue engineering scaffolds [23, 24], as well as controlled drug delivery systems [25-27].
Besides synthesis of poly(lactic-co-glycolic acid), as a prosperous practice in modification of polymer properties, such as crystallinity, melting point and degradation rates, preparation of copolymers of lactic and glycolic acids with other monomers (e.g $\varepsilon$-caprolactone, $\delta$-valerolactone or 1,5 dioxepan-2-one) has also been applied [15,28, 29].

\section{APPLICATION OF BIODEGRADABLE POLYMERS IN TISSUE ENGINEERING}

Tissue engineering as an interdisciplinary approach in treatment of patients suffering from dysfunctional organs (e.g. liver, pancreas) or loss of tissues has been constantly developed. Scaffolds used for tissue engineering as bone, cartilage, ligament, skin, vascular and neural tissues, skeletal muscles, and as vehicles for the controlled delivery of drugs, proteins, and DNA, overcome basic restrictions of the conventional therapies, such as limitations in the provision of tissue donors, as well as restrictive function of prosthesis or mechanical devices $[8,12]$.

Fundamental techniques of tissue engineering have been grouped into the following categories [30]: (1) matrices used as substrates or encapsulating materials of cells, (2) controlled supply of tissue-promoting substances (e.g. growth factors), and (3) implants of isolated cells or cell substitutes into the organism. The first of these concepts, which has been mostly related to the concept of tissue engineering, is mainly based on "seeding" of isolated living cells or cell clusters taken from tissue donor onto appropriate extracellular scaffolds, i.e. in vitro cultivation of cells, and implantation of such a system into an organism as required. By the application of this strategy, sacrifice of entire donor organ is avoided, which is considered as an advantage over the traditional transplantation interventions.

The role of biodegradable scaffolds has not been merely a simple mechanical support during tissue healing, but, the need of their simultaneous degradation has been taken into account. In addition, degradation rate of polymer matrices, corresponding to the rate of tissue restoration, makes the design of new polymer materials for tissue engineering applications a significantly challenging task [23, 24].

Several conventional techniques have been used in preparation of porous matrices: solution evaporation techniques, phase separation, electrospinning, freeze drying, shape moulding, gas foaming, but also techniques of solid freeform fabrication (SFF), such as three dimensional printing, stereo-lithography, fused deposition modelling (FDM), as well as phase-change jet printing [31] have not been extraneous. 
Physical and chemical requirements that matrices used in tissue engineering have to accomplish are: (1) porous structure that will support proliferation, differentiation and organization of cells in three dimensional (3D) structures, i.e. it will assist the integration of tissue and vascular system, (2) to be fabricated by biocompatible and bio-absorptive material with controlled biodegradation and resorption rate, concurrently supporting its replacement by a newly progressively growing tissue, (3) appropriate surface chemistry and architecture allowing "attachment", differentiation and proliferation of cells, (4) to achieve suitable mechanical properties and to be fitted to the appropriate implantation place, (5) to act as a system for controlled release of biomolecular species, e.g. growth factors, (6) to prevent certain adverse reactions and (7) to be easily processed into different shapes and sizes [32].

The proper control of the pores size, their distribution in the matrix, shape and morphology, promotes the success of seeding and attachment of the cells, the growth and vascularization of a new tissue, as well as the provision of flow of nutrients and metabolites toward and outside the implants [33].

Proper choice of matrices holding particular mechanical properties and programed degradation features aids the proliferation of a new tissue of requiring morphology. Scaffolds prepared of synthetic polymers provide mechanical support suitable for in vivo stresses, and at the same time maintain the cells growth until the integrity of the new tissue has not been achieved. Cells as integrated part of the newly formed tissue produce genes assisting restoration of the complex biochemical environment and preservation of its specific functions. The function of the "planted" cells is highly dependent on: the number and the type of surface receptors (e.g. proteins) capable of interactions with cells; interplay with the neighbouring cells, as well as the existence of the growth factors in the scaffolds. The presence of the biologically active molecules (growth factors, antigenic factors and/or immunosuppressive agents) in the polymer matrices provides indivisible relation of both, tissue engineering and controlled drug release technologies [32].

The potential of cell transplantation in the regeneration of soft and hard tissues has been increased by the development and preparation of polymer scaffolds suitable for tissue proliferation, in both, in vitro and in vivo establishments.

Opportunities offered by modification of properties of polymers and copolymers based on lactic and glycolic acid have been one of the reasons for their successful application as tissue engineering scaffolds. As it was previously mentioned, suitable techniques in modification of mechanical features are synthesis of copolymers with other monomers or preparation of blends with polylactones, polyethers, poly(amino acids), polycarbonates, polyurethanes and other polymers of natural and synthetic origin [34-37].

Possible interactions between implanted biodegradable polymers and surrounding tissues promote appropriate cell proliferation and tissue regeneration. This is additionally encouraged by incorporation of bioactive molecules into polymer matrices and / or by the surface modification of the inserted material [38, 39].

Tissue engineering scaffolds have been biochemically patterned through many different approaches. For example, materials of bigger biocompatibility have been prepared by chemical bonding of short siloxane blocks to the homo and copolymers of lactic and glycolic acids and / or mixing them in appropriate ratios resulting in materials suitable for soft tissues support or controlled drug release devices [40, 41].

Hybrid systems constructed of materials of both, natural and synthetic origins have comprised combined properties including mechanical and degradation properties, reproducibility in manufacturing, as well as application of simple fabrication techniques characteristic for synthetic polymers and the specific biological activity of natural materials [42-44]. Thus, coatings of hydroxyapatite at the surface of porous PLA enhance the cells adhesion to the matrix [42] and promote their migration in the composite material. Such systems allow sustained cells existence compared to the neat PLLA. Polymer scaffolds coated with collagen [44] have been applied in bone regeneration, and renewal of blood vessels and nerves [14]. Similarly, fibres and disks of cellulose-graft-L-lactide copolymers with different lengths of grafted PLLA have been prepared [45]. Non-toxic and biocompatible polymer networks have been created using polysaccharides, for instance chitin and chitosan, and macromeres of poly(ethylene glycol)-copoly(lactones)di-acrylate [46].

It has been shown that chemical modification of lactic-co-glycolic acid copolymers with amino acids facilitates attachment of active components to the polymer. Ring-opening polymerization of mofolin2,5-dione derivatives is a convenient method for synthesis of wide range of poly(ester amides), such as: 3-(o-benzyl)-L-serine morpholine-2,5-dione, poly(L-serine-alt-glycolic acid), poly(glycolic acidco-L-serine-co- $\varepsilon$-caprolactone), poly(glycolic acidco-L-serine-co-L-lactic acid) [47, 48], poly[(glycolic acid)-alt-(L-glutamic acid)], poly\{(L-lactic acid)-co- 
[(glycolic acid)-alt-(L- glutamic acid)]\} [49], etc. Modification of biodegradable copolymers PLLAPEG-PLLA with L-aspartate has been promoted as one of the strategies for enhancement of affinity of

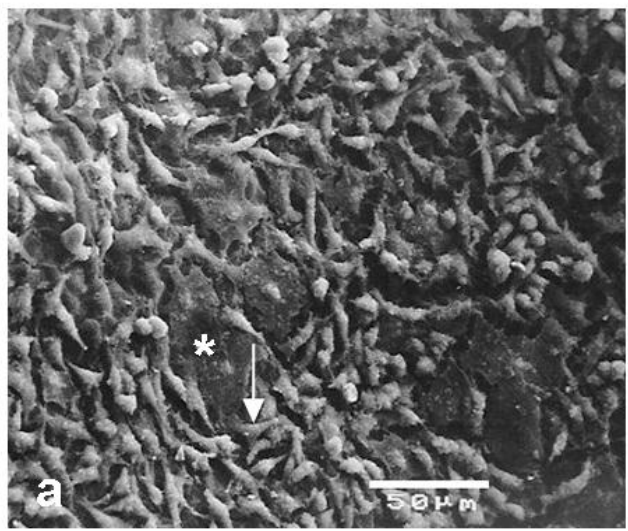

cells toward polymer substrates. Functional groups existing in the aspartate block have been adequate for covalent bonding of polypeptides or proteins $[50,51]$.

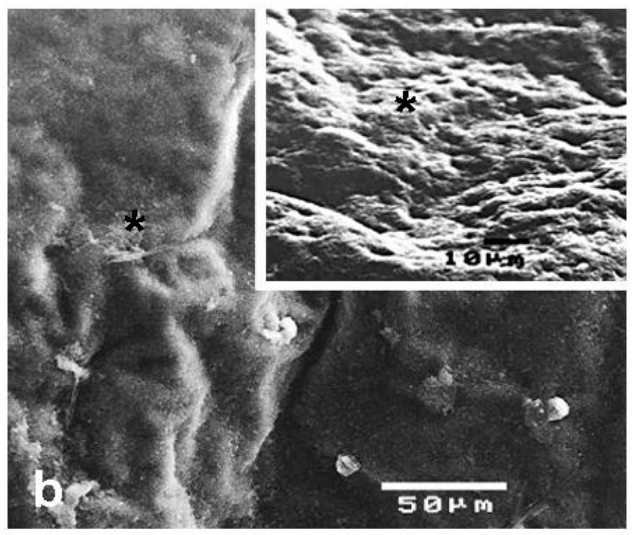

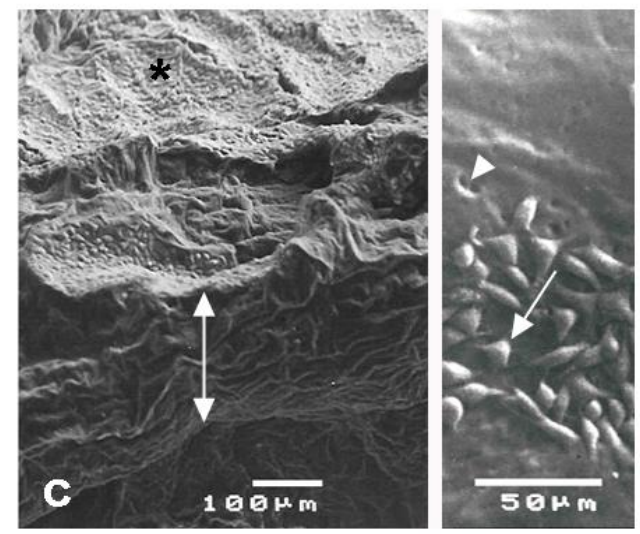

Figure 1. Scanning electron microscope (SEM) microphotograph taken $72 \mathrm{~h}$ after mouse fibroblasts $L 929$ are seeded in vitro on surfaces prepared of: (a) Poly(DL-lactide-co-glycolide) (PDLLG); (b) Poly(ethylene glycol)-poly(DL-lactide-co-glycolide)-poly(ethylene glycol) (PEG-PDLLGA-PEG) triblock copolymer activated with N-hydroxylsuccinimide (NHS) (PEG-PDLLG-NHS) and (c) Collagen modified PEG-PDLLGA-PEG (PEG-

PDLLG-Col). Surfaces are denoted by asterisks, while presence of the cells is shown by an arrow. Double-sided arrow indicates the cross-section of the film [13].

Slika 1. SEM mikrofotografije snimljene $72 \mathrm{~h}$ nakon zasađivanja ćelija i rasta $L 929$ fibroblasta $u$ in vitro uslovima, podloge na bazi: (a) poli(laktid-ko-glikolid) (PDLLGA); (b) poly(ethylene oxide)-poly(DL-lactic acid)poly(ethylene oxide) triblock kopolimer modifikovanim sa N-hidroksilsukcinimidom (NHS) (PEG-PDLLG-NHS) $i$ (c) kolagen modifikovanim PEG-PDLLG-PEG (PEG-PDLLG-Col). Površine su označene zvezdicom, dok su fibroblasti potencirani strelicom. Naprečni presek je označen dvojnom strelicom [13].

Modification of poly(ethylene glycol)-poly(DLlactide-co-glycolide)-poly(ethylene glycol) (PEGPDLLG-PEG) tri-block copolymer with collagen has been successfully performed. Activation of the copolymer for coupling with collagen has been made by reaction of carboxyl end- groups of PEGPDLLG-PEG with N-hydroxylsuccinimide (PEGPDLLG-NHS) and at the end Type I collagen has reacted with PEG-PDLLG-NHS (PEG-PDLLG-Col). The degree of cell proliferation compared between pure PDLLGA, PEG-PDLLG-NHS and PEGPDLLG-Col indicated significant increase of number of cells on the surface modified with collagen, Figure 1 [13].
Furthermore, the success of regenerative treatments has been encouraged by growth factors [52] and other biological agents encapsulated into controlled release systems [53].

Most of the understandings of tissue engineering have been based on the application of simple in vitro two-dimensional cell cultures that fail in mimicking the complexity of exctracellular microenvironment. In addition, preservation of the activity of biological entities in functionalized polymer substrates has been the basic concern in tissue engineering treatments $[54,55]$. Hence, the recently developed idea of biomimetic approach 
based on three-dimensional models simulating extracellular matrices has been very successful in protection of payload of bioactive components [56], as well as much more effective in complete reproduction of tissue complexity than their twodimensional counterparts [57].

Spadaccio et al. have demonstrated that functionalization of the PLLA biopolymer with granulocyte colony-stimulating factor (GCSF), tested as a ventricular patch in a rabbit chronic model of myocardial infarction, induced an angiogenetic process with a significant increase in the number of new vessels compared to the nonfunctionalized scaffold [58].

Lately, novel approaches using small molecules instead of growth factors have been applied in tissue regeneration treatments. Characteristics as stability, tunability, and low cost have been considered as advantage of small synthetic molecules compared to the higher molecular mass biomolecules. Pandolfi et al. [59] prepared chitosan-gelatin scaffolds functionalized with composite microspheres consisted of silicon microparticles and poly(DL-lactic-co-glycolic acid) for the controlled release of small molecules such as sphingosine-1-phospate. Such complex systems have a crucial role in regenerative processes; they provide both, extracellularity, which controls cell migration, and intracellularly that improves cell survival and proliferation.

Biocompatible conducting polymer scaffolds have been shown to be valuable in musculoskeletal and endothelial tissue engineering interventions [60]. Novel "fluffy" polypyrrole (PPy) fibrous scaffolds contribute to a bigger cardiomyocyte differentiation compared to tissue culture plates [61]. Gemli et al. [62] have proven the influence of physical properties and surface roughness of PPy materials on the success of cardiac stem cells proliferation [62]. Electrochemical synthesis of conductive polymers allows incorporation of counter ions dopants that are either inorganic polyelectrolytes or molecules with biological activity. Non-cytotoxic dopants supporting cellular growth such as polysaccharides hyaluronic acid (HA), chondroitin sulphate (CS) [63-65], polysaccharide dextran sulphate (DS), dodecylbenzenesulfonic acid (DBS), polystyrene sulfonate (PSS), and $p$-toluenesulfonic acid (pTS) have been commonly used in preparation of PPy substrates [66-68]. Electrically conductive biodegradable composite material made of polypyrrole (PPy) nanoparticles and poly(DL-lactide) (PDLLA) has been shown to be a material that supports growth of fibroblasts under the stimulation of medium range intensity of DC current [69].
The aforementioned experiences in terms of design of superior biopatterned systems for tissue engineering applications, experiencing high biocompatibility and improved cell proliferation and differentiation, indicate the essential need of joint arrangements between 2D/3D biodegradable scaffolds with micro- or nano- formulations able to accomplish temporally and/or spatially controlled release of bioactive molecules.

\section{APPLICATION OF BIODEGRADABLE POLYMERS IN CONTROLLED DRUG DELIVERY SYSTEMS}

Controlled delivery or controlled release of active substance covers: delivery of previously determined quantity, with a "programmed" rate to a certain place, in a previously determined period of time, providing optimal effect of the active species.

Systems for controlled release have been already applied in agriculture for continuous provision of optimal concentration of nutrients, insecticides, herbicides and other agrochemicals; in architecture [70]; cosmetic and food industry [71]; but the biggest challenge is their application in the medicine and pharmaceutical industry for controlled and targeted release of active substances [72, 73].

Drug delivery systems might be divided into two general groups: controlled drug release systems and systems for selective targeting of drugs (drug targeting). Accordingly, the drug release can be governed by time depended processes, such as polymer matrix degradation; or it can be in control of drug diffusion [74].

Systems for controlled and targeted release of active molecules consist of: prodrugs, macromolecular prodrugs, antibody-drug conjugates, medicaments chemically bonded to polymer carriers, as well as systems in a shape of particles.

Particulate systems encompass liposomes and solid colloid carriers in the form of micro- and nanoparticles [75].

Polymers are considered as the most convenient materials in pharmaceuticals fabrication, particularly due to the possibility for modifications and drug permeability control. Furthermore, incorporation of biological agents into polymer systems could be accomplished by physical or chemical methods. In this regard, a polymer can take a role of a microcapsule, reservoir with core-shell structure, and an active component can be dispersed or dissolved throughout solid matrix known as microspheres or carriers where drugs are chemically bonded to the polymer $[72,76,77]$. These structures distribute the active substances to the desired place with a previously determined rate in a 
defined time period that is enabled by the concurrent polymer degradation. Nontoxic degradation products of low molecular masses have been removed from the organism by the normal metabolic processes.

Increased therapeutic activity of the drug, lowered number of side effects, decrease in the number of physicians needed, reduced toxicity, and improved patients' tolerance are some of the advantages of the systems of controlled drug release over conventional dosage methods [25].

According to the above mentioned, the following mechanisms of drug delivery could be recognized [74]:

- Diffusion dependent mechanisms that are: diffusion processes through porous or semipermeable polymer membranes; matrices (lipophilic, hydrophilic and porous polymers) and microreservoirs (hydrophilic reservoir-lipophilic matrix and lipophilic reservoir-hydrophilic matrix).

- Triggered processes i.e. stimulated and controlled by: osmotic pressure, hydrodynamic pressure, magnetism- physically controlled targeted delivery systems, ultrasound, $\mathrm{pH}$, ions and temperature.

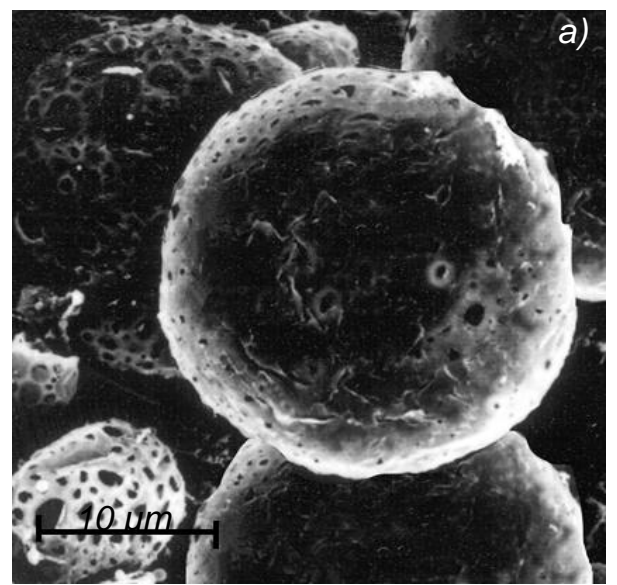

- Chemical processes, i.e. chemically controlled processes: degradation/erosion of polymer matrix and chemical bond cleavage (so called actively targeted delivery systems).

Preparation of controlled drug delivery systems involves three groups of polymers [72]: water soluble (e.g. poly(ethylene glycol), poly(vinyl alcohol), polyacrylamide, poly(methacrylic acid), etc.), biodegradable (e.g. poly(lactic acid), poly(glycolic acid), polyanhydrides, polydioxanone, poly(orthoesters), polyalkylcyanoacrylates, etc.), and non-biodegradable polymers (e.g. silicones, polyethylene, polymethacrylates, etc.). Biocompatible polyesters subjected to hydrolytic degradation have been considered essential in the preparation of drug delivery systems [78]. In this regard, particular attention has been paid on biodegradable synthetic polymers such as PLA, PLGA, but natural polymers as gelatine and albumin have been also applied $[79,80]$. Criteria that resorbable polymers used as drug carriers need to fulfil are: acceptable half-life periods, compatibility to the environment in which systems are inserted, non-toxicity, compatibility with the biological agents without chemical or physical interactions between them, as well as good mechanical features [81].

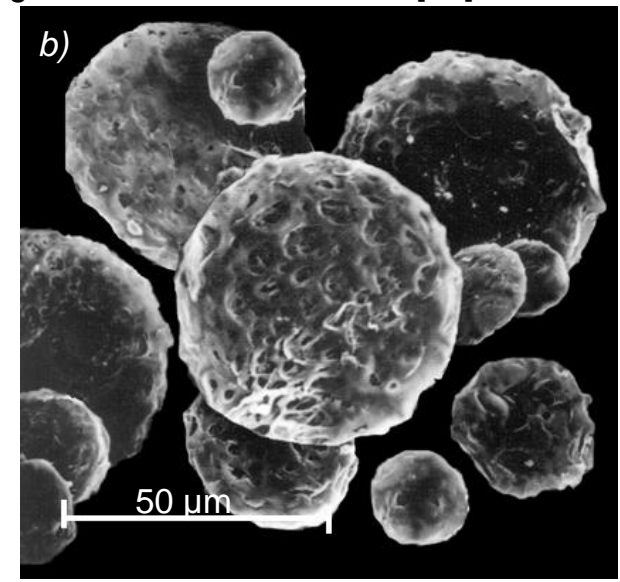

Figure 2. SEM photos of bovine serum albumin (BSA) encapsulated poly(lactic-co-glycolic acid) (PLGA) microspheres (a) poly(DL-lactic-co-glycolic acid) PDLLGA with molar mass of $\mathrm{Mw}=44700 \mathrm{~g} / \mathrm{mol}$ and polydispersity index (PDI) 1.68 with a ratio DL-lactic acid/glycolic acid = 80/20 wt/wt; (b) poly(L-lactic-coglycolic acid) (PLLGA) with molar mass of $M w=88000 \mathrm{~g} / \mathrm{mol}$ and $P D I=1.95$ with a ratio L-lactic acid/glycolic acid $=68 / 32$ wt/wt [78]

Slika 2. Skenirajuća elektronska mikroskopija (SEM) PLGA mikrosfere sa inkapsuliranim bovin serum albumin (BSA) (a) PDLLGA sa molarnom masom Mw = $44700 \mathrm{~g} / \mathrm{mol}$ i indeks polidisperznosti (PDI) 1.68; odnos DL-mlečna kiselina/glikolna kiselina = 80/20 wt/wt; (b) PLLGA sa molarnom masom Mw $=88000$ g/mol i PDI = 1.95; odnos L-mlečna kiselina/glikolna kiselina = 68/32 wt/wt [78].

PDLLGA and PLLGA copolymers of different molar masses have been used for preparation of protein, bovine serum albumin (BSA), encapsulated microspheres by the double emulsion water-in- oil-in-water (w/o/w) method, Figure 2 [78]. It has been found that the copolymers of higher molar masses provide higher solution viscosity and thus microparticles of higher sizes. Bigger glycolide 
content ensures increased hydrophilic segments in the polymer which promotes interaction with protein, and prevents its diffusion out of the microspheres. Preservation of physical and chemical stability of proteins after encapsulation and release has been considered as a serious problem in such or similar drug delivering formulations. A lot of investment has been done to overcome this problem by selection of appropriate techniques of microspheres preparation such as spray- or spray-freeze drying protocols [82].

Biodegradable PLGA microspheres have been used in encapsulation of hormone Leuprolide [83], in the vaccine delivery, e.g., subunit tuberculosis vaccine (Ag85B-ESAT-6) [84], but also in various cancer treatments [85]. So, it was shown that PLA loaded microspheres with intratumoral interleukin 12 (IL-12), tumour necrosis factor (TNF), and granulocyte-macrophage colony stimulating factor (GM-CSF) have produced antitumor response in a murine model of breast cancer [86]. Similarly, paclitaxel-encapsulated PLGA microspheres significantly inhibited lung tumour growth in vivo [87], and antigen CA125 loading in PLGA microspheres showed significant $\mathrm{T}$-cell proliferation in vitro as well as promising response during ovarian cancer therapy [88].

It has been considered that water insoluble polymers or biodegradable polymers are favoured in oral applications, but for preparation of implantable and ocular systems non-biodegradable polymers are preferable. The size of particles has been determined by factors, such as: area of application, dosage of active substance, administration technique, i.e. oral, nasal, buccal, ocular, rectal, transdermal, injection or implantation. Hence, drug carriers of micro- or nano- dimensions have been easily injected in the body [89].

As far as oral administration is concerned, regarding their size, microparticles are incapable to cross the mucosal barrier of gastrointestinal tract, resulting in a drug delivery failure. Such a disadvantage of microparticles has been solved by application of their nanosized counterparts. Different biomolecules, vaccines, genes, proteins, drugs, etc., have been encapsulated or conjugated at the surface of polymer based nanoparticles. Advantages of nanoparticles dosage systems for intra-arterial localization of therapeutic agents include: subcellular size, targeted surfaces, good suspensibility, as well as facilitated penetration into the arterial wall without trauma causation [90].

The problem of rapid removal by mononuclear phagocytic system in vivo via intravenous route has been solved by nanoparticles surface modification with biomolecules found normally in the body [91,
92]. Surface modified nanosized particles have been designed for a long term circulation within the blood vascular system in a fashion that allows their targeting to a specific part of the body (tumour cells, brain, liver, lungs, etc.).

Several hydrophilic polymers, such as poloxamers, polysorbate 80 , TPGS, polysorbate 20 , polysaccharides like dextran and different type of copolymers have been used as coatings [93, 94], but the most preferable method for surface modification is the adsorption or grafting of poly (ethylene glycol) (PEG) to the nanoparticles surface. It has been assumed that the increased circulation time of the nanoparticles in blood is mainly due to steric repulsion of hydrated barriers created by PEG preventing proteins adsorption and thus postponing the immune processes in the body [95].

In addition to this, attachment of imaging agent to the surface enables micro- and nanoparticles application not merely in the therapeutics, but in diagnostic purposes as well [96, 97]. Nanoparticles preparation procedures have been selected based on the type of the active substance incorporated, targeted organs, as well as drug release mechanism.

Arrangements of nanoscaled dimensions, known as micelles, prepared from amphiphilic polymers containing biodegradable component (e.g. lactic acid) $[98,99]$, have drawn big attention regarding the capability of incorporating two different active substances or the possibility of surface functionalization for selective drug targeting processes. Polymer based micelles generally have spherical shape sized from 10 to $100 \mathrm{~nm}$ [100] and core - shell architecture where segments dissolved in a particular solvent form the outer shell stabilizing the inner hydrophobic core [101, 102]. Important class of macromolecular surfactants are non-ionogenic block copolymers with polyoxyethylene hydrophilic part, while hydrophobic part is usually built of poly(propylene oxide) (PPO) [103], poly(butylene oxide) (PBO) [104] or biodegradable polymers, such as poly( $\beta$-benzyl-L-aspartate) (PBLA) [105], poly((L)DL-lactic acid) (PLLA, PDLLA) [98, 99, 104], poly(lactic-co-glycolic acid) (PLGA) [106] or poly ( $\varepsilon$ - caprolactone) (PCL) [107, 108]. Hydrophobic cores in the micelles serve as reservoirs of hydrophobic drugs protecting them from contact with aqueous solvents [109]. Incorporation of the active components in the micelles could be accomplished by chemical conjugation or by physical incorporation by dialysis or emulsification [100]. 


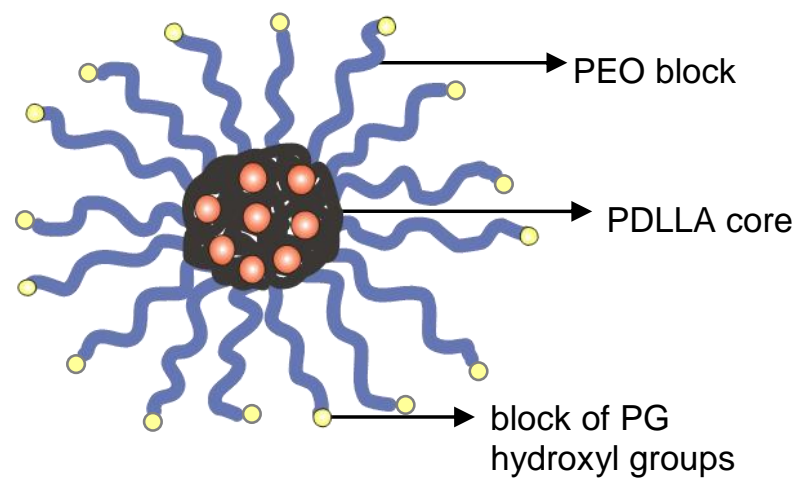

Figure 3. Model of polyglycidol-poly(ethylene oxide)-poly(DL-lactic acid) triblock copolymer nanoparticles in the form of micelles [98, 99].

Slika 3. Model micela na bazi poliglicidol-poly(etilen oksid)-poli(DL-mlečna kiselina) kopolimera nanočestice u formi micela [98, 99].
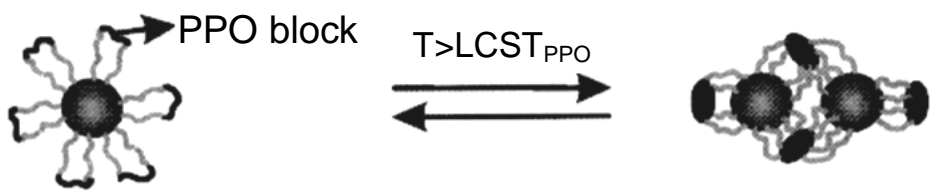

Figure 4. Aggregation of poly(DL-lactic acid)-poly(ethylene oxide)-poly(propylene oxide)-poly(ethylene oxide)- poly(DL-lactic acid) (PDLLA-PEO-PPO-PEO-PDLLA) pentablock copolymers [98].

Slika 4. Agregati na bazi poli(DL-mlečna kiselina)-poli(elilen oksid)-poli(propilen oksid)-poli(elilen oksid)poli(DL-mlečna kiselina) (PDLLA-PEO-PPO-PEO-PDLLA) pentablok kopolimera [98]

Polyglycidol-poly(ethylene oxide)-poly(DL-lactide) (PG-PEO-PL) triblock copolymers and poly(DLlactide)-poly(ethylene oxide)-poly(propylene oxide)poly(ethylene oxide)-poly(DL-lactide) (PL-PEOPPO-PEO-PL) pentablock copolymers have been synthesized in order to obtain precursor architecture suitable for drug delivery systems [98, 99]. The chemical composition of PG-PEO-PL provides formation of highly hydroxyl functionalized micelles in aqueous media, taking "hairy" structure as presented in Fig. 3. [98]. The core of the micelles is formed by hydrophobic polylactide block, while the hydrophilic shell is made of polyethylene oxide block with polyglycidol hydroxyl groups on the end that opens an attractive approach for attachment of drug-targeting agent [98, 99].

On the other hand, micellization of thermosensitive PL-PEO-PPO-PEO-PL pentablock copolymers starts at a given critical micellization concentration $(\mathrm{cmc})$ or critical micellization temperature $(\mathrm{cmt})$. At the concentrations above $\mathrm{cmc}$ and temperatures below lower critical solution temperature (LCST) of PPO, PL-PEO-PPO-PEO-PL creates flower-like micelles as it is given in Figure 4 (structure on the left). Above LCST, PPO blocks become dehydrated and PPO chains form a second hydrophobic domain. Such a structure can participate in immobilization of two active components, one in the PL core and the other in the PPO regions [98].

An anticancer drug, paclitaxel (PTX), loaded micellar formulations based on thermo-sensitive and degradable amphiphilic polyaspartamide derivatives (phe-g-PHPA-g-mPEG) have been prepared by $\mathrm{Ma}$ et al. [110]. Likewise, star-shaped and Y-shaped amphiphilic block copolymers using hydrophobic PCL and hydrophilic PEG for anticancer treatments have been also synthetized. Yet, micelles consisted of Y-shaped block copolymer have been found to facilitate delivery of hydrophobic anticancer drugs [111].

Glutathione (GSH)-responsive poly(ethylene glycol)-b-polycarbonate-b-poly(ethylene glycol) micellar nanoparticles carrying hydrophobic anticancer drugs, have shown glutathione-triggered decomposition controlling the drug release and at the same time the cytotoxicity to cancer cells [112].

Nevertheless, polymeric micelles have been mainly studied as delivering systems for anticancer drugs $[113,114]$; they are convenient devices for transport of plasmid DNA, oligonucleotides [115] or diagnostic agents [116].

Generally, drug release kinetics is highly governed by the solubility, the strength by which drug is bounded / adsorbed to the particle surface, degradation mechanism of polymer matrix, 
diffusion profile of active substance, as well as a combination of diffusion and degradation processes [117]. The application of polymers of different lengths, consequently varied degradation rates, has been considered as one of the suitable techniques of regulation of drug release rates [92, 118]. As it was shown [78] for BSA-loaded microspheres, initial release of BSA has been observed for microparticles prepared of polymers with higher molar mass as well as higher contents of hydrophilic segments. Higher molar mass polymers give bigger viscosity of their solutions resulting in the faster hardening of microparticles, while prevented protein diffusion out of microspheres has been related to the increased interactions with hydrophilic polymer regions. In the later phases, matrices erosion is considered to control the drug release from the core of the microparticles.
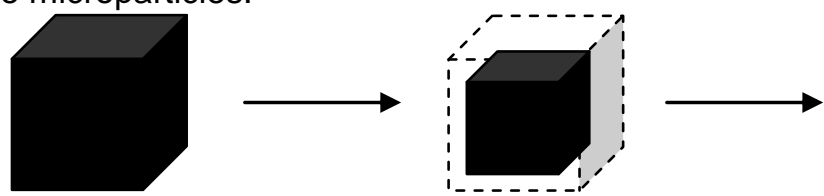

\section{MECHANISMS OF HYDROLYTIC DEGRADATION}

Biodegradation is defined as a process of "gradual scission of the polymer chain backbone" by the mechanisms of enzymatic and non-enzymatic hydrolysis in a physiological environment. Thus, to define a polymer as biodegradable, one should contain easily hydrolysed species, such as ester, anhydride, orthoester and amide groups [74, 119-121].

The concept of "degradation" is related to the cleavage of the covalent bonds in the main and side polymer chains, while "erosion" denotes the process of material disappearing. Degradation is a chemical process, and erosion is a physical phenomenon, which is based on the processes of dissolution and diffusion.

Figure 5. Model of idealized surface erosion of polymers [121, 122].

Slika 5. Model idealizovane površinske erozije polimera [121, 122].

Two mechanisms of polymer erosion could be identified: surface erosion, Figure 5 and bulk erosion, Figure 6, which are the two extreme cases. Most of the biodegradable polymers

deteriorate by the two mechanisms, but which of the two mechanisms will be dominant depends on the chain structure [74, 119-121].
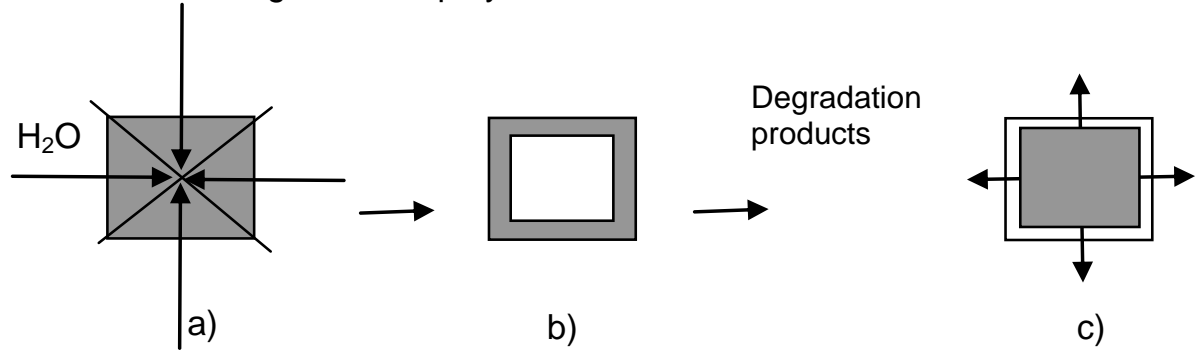

c)

Figure 6. Model of bulk erosion of polymers: (a) diffusion of water in the material; (b) degradation products are concentrated in the centre of the sample, autocatalytic reaction; (c) diffusion of oligomers with satisfying small molar mass through less degraded surface (skin) into the outer medium [121].

Slika 6. Model polimerne erozije u masi: (a) difuzija vode u materijalu; (b) koncentrisanje degradacionih produkta u centru primerka, autokatalitička reakcija; (c) difuzija oligomera sa zadovoljavacući niskom molarnom masom kroz manje degradiranoj površini u spoljni medijum [121].

Surface erosion is a desired mechanism in polymers used as matrices for controlled and targeted drug release. The small rate of water penetration in the interior of the systems at the time of erosion protects the stability of medicaments in aqueous environments [122]. It was found that polyanhydrides, poly(ortho esters), polyphosphazenes, and poly(anhydride-co-imides) as hydrophobic polymers deteriorate regarding surface erosion mechanism [74, 119, 120]. Drug delivery systems degrading by the mechanism of surface erosion provides delivery rate of the active molecules of $0^{\text {th }}$ order.

Bulk erosion, which is typical for polyesters, is characterized with faster water molecules penetration in the polymer matrix compared to the one of surface erosion. Degradation of polyesters is described by so called interior erosion that could be accomplished in homogeneous or heterogeneous manner. 
Homogeneous "bulk" erosion is carried out in two stages. At the beginning, water enters the sample and the chain fragmentation is initiated by hydrolyses of ester bonds. In the second stage, the fragments hydrolyse to products soluble in water. It has been noticed that in the polymers degraded by this mechanisms, both, mass and molar mass reduction occur simultaneously.

Heterogeneous degradation (Figure 6) is characterized by: discontinuity in the mass loss and water uptake, as well as changes in $\mathrm{pH}$ at the place of hydrolytic degradation. At the beginning, buffer penetrates in the sample smoothly triggering homogeneous hydrolysis, insignificant mass loss of polymer and slower water uptake (first phase, Figure 6). When critical molar mass of polymer is achieved, the second stage of heterogeneous degradation follows. Oligomers with higher length in the inner part of the implant are not able to diffuse outside, toward medium, so that the increased concentration of carboxyl end groups catalyses the hydrolysis in the interior of implants [120]. An insignificant diffusion of degradation products from the internal parts of the system explains the reason of uncoordinated processes of mechanical properties deterioration and polymer molar mass decrease. On the other hand, shorter oligomers existing closer to the sample surface diffuse into aqueous medium leaving porous areas. Higher molar mass oligomers, positioned near the implant surface, ensure lower number of carboxyl groups realising lower catalytic effect and slower hydrolysis inside the system. Water molecules penetrating into porous regions of the sample assist the diffusion of lower molar mass oligomers toward aqueous medium (third phase, Figure 6) $[123,124]$.

Polymer degradation has been mainly promoted by the presence of: hydrophilic monomers, hydrophilic end-groups, hydrolytically reactive groups in the polymer chain, lower polymer crystallinity, as well as smaller dimensions of particulate formulations [123, 124]. Degradation processes were promoted in PLGA copolymers containing bigger amount of glycolide, in systems with amorphous morphology, and also higher molecular mass polymers. Regarding autocatalytic effect in PDLLA, faster degradation in the centre compared to the surface of the system has been observed [120].

The degradation process of biodegradable polymers might be completed within a period of several weeks to several years $[74,120,121]$ which is tailored by chemical composition and polymer structures.

\section{CONCLUSION}

Biodegradable polymers are considered as materials suitable for large area of applications with particular attention paid on their medical and pharmaceutical practice. Unique properties, such as biodegradability, cell proliferation assistance and new tissue integrity, as well as easy processing, make them very attractive in preparation of tissue engineering and drug delivery systems. In order to improve biocompatibility of engineered systems, a lot of techniques, such as preparation of copolymers, blends or composite materials including both, natural and synthetic polymers, have been applied. Many scholars have designed materials containing some regions that look like native tissue, but failed in total biochemical and mechanical similarity. In order to overcome this and similar drawbacks, joint efforts of tissue engineering and pharmaceutics formulations are necessary.

This review article aims to serve as an encouragement for further improvements of three dimensional bioresorbable / biodegradable patterned arrangements successful in mimicking the complex behaviour of targeted tissues, and at the same time able for temporally and/or spatially controlled release of bioactive molecules.

\section{REFERENCES}

[1] B.D.Ratner, A.Hoffman, F.Schoen, J.Lemons (2004) Biomaterials Science: An introduction to Materials in Medicine, Elsevier Academic Press, Waltham, MA, USA.

[2] J.Davis, Davis \& Associates (Eds.) (2003) Handbook of Materials for medical devices, ASM International, Ohio.

[3] P. A. Gunatillake, R. Adhikari (2003) Biodegradable Synthetic Polymers for Tissue Engineering, European Cells and Materials, 5 (1), 1-16.

[4] J. Sun, H.Tan (2013) Alginate-Based Biomaterials for Regenerative Medicine Applications, Materials, 6 (4), 1285-1309.

[5] M.Prabaharan, P.R. Sivashankari (2016) Prospects of Bioactive Chitosan-Based Scaffolds in Tissue Engineering and Regenerative Medicine, book Chitin and Chitosan for Regenerative Medicine, Springer, New Delhi, pp 41-59.

[6] F. Menaa, A. Menaa, B. Menaa (2011) Hyaluronic Acid and Derivatives for Tissue Engineering, Journal of Biotechnology \& Biomaterials, S3, 001.

[7] H.-J.Lee, S.-H.Ahn, G.H.Kim (20112) ThreeDimensional Collagen/Alginate Hybrid Scaffolds Functionalized with a Drug Delivery System (DDS) for Bone Tissue Regeneration, Chem. Mater., 24 (5), 881-891.

[8] A. Asti, L. Gioglio (2014) Natural and synthetic biodegradable polymers: different scaffolds for cell expansion and tissue formation, Int. J. Artif. Organs; 37(3), $187-205$. 
[9] K. Tur (2009) Biomaterials and Tissue Engineering for Regenerative Repair of Articular Cartilage Defects, Rheumatology, 24 (4), 206-217.

[10] J.F.Mano, R.A.sousa, L.F. Boesel, N.M. Neves, R.L. Reis (2004) Biointert, biodegradable and injectable polymeric matrix composites for hard tissue replacement: state of the art and recent developments, Composites science and Technology, 64 (6), 789-817.

[11] H.R.Rezaie, L.Bakhtiari, A.Öchsner (2015) Biomaterials and Their Applications, Springer, New York.

[12] A. R. Amini, J.S.Wallace, S.P. Nukavarapu (2011) Short-Term and Long-Term Effects of Orthopedic Biodegradable Implants, Journal of Long-Term Effects of Medical Implants, 21 (2), 93-122.

[13] A.Porjazoska, O.Karal-Yilmaz, K.Baysal, M. Cvetkovska, S. Sirvanci, F. Ercan, B. M. Baysal (2006) Synthesis and characterization of poly(ethylene glycol)-poly(D,L-lactide-co-glycolide) poly(ethylene glycol) triblock copolymers modified with collagen: a model surface suitable for cell interaction, Journal of Biomaterials Science, Polymer Edition, 17 (3), 323-340.

[14] B.Seal, T.Otero, A.Panitch (2001) Polymeric biomaterials for tissue and organ regeneration, Mater.Sci. Eng. R:Reports, 34 (4-5), 147-230.

[15] J.Middleton, A.Tipton (2000) Synthetic biodegradable polymers as orthopaedic devices, Biomaterials, 21 (23), 2335-2346.

[16] B. X. Fu, B. S. Hsiao, G.Chen, J. Zhou, I. Koyfman, D.D.Jamiokowski, E. Doemier (2002) Structure and property studies of bioabsorbable poly(glycolideco-lactide) fiber during processing and in vitro degradation, Polymer 43 (20), 5527-5534.

[17] K.Hamad, M.Kaseem, H.W.Yang, F.Deri, Y.G.Ko (2015) Properties and medical applications of polylactic acid: A review, Express Polymer Letters 9 (5), 435-455.

[18] A.Södergard, M.Stolt (2002) Properties of lactic acid based polymers and their correlation with composition, Prog. Polym. Sci., 27 (6), 1123-1163.

[19] A.U.Daniels, M.K.O.Chang, K.P.Andriano, J. Heller (1990) Mechanical properties of biodegradable polymers and composites proposed for internal fixation of bone, J. Appl. Biomater., 1 (1), 57-78.

[20] C.W.Lou, C.H.Yao, Y.S.Chen, T.C.Hsieh, J.H.Lin, W.H.Hsing (2008) Manufacturing and properties of PLA absorbable surgical suture, Textile Research Journal, 78 (11), 958-965.

[21] B.D.Ulery, L.S.Nair, C.T.Laurencin (2011) Biomedical applications of biodegradable polymers, J. Polymer Sci. Part B Polymer Phys., 49 (12), 832-864.

[22] S. Park, J.H. Kim, I.H. Kim, M. Lee, S. Heo, H. Kim, E.H. Kim, Y.B. Choy, C.Y. Heo (2013) Evaluation of poly(lactic-co-glycolic acid) plate and screw system for bone fixation, J. Craniofac. Surg., 24 (3), 1021-1025.

[23] D. J. Mooney, D. F. Baldwin, N. P. Suh, J. P. Vacanti, R. Langer (1996) Novel approach to fabricate porous sponges of poly(DL-lactic-co-glycolic acid without the use of organic solvents, Biomaterials, 17 (14), 1417 1422.

[24] T. Perisic, Z. Zhang, P. Foehr, U. Hopfner, K. Klutz, R.H. Burgkart, A. Slobodianski, M. Goeldner, H.-G. Machens, A. F. Schilling (2017) Biodegradable poly (lactic acid-co-glycolic acid) scaffolds as carriers for genetically-modified fibroblasts. PLoS ONE 12(4): e0174860

(https://doi.org/10.1371/journal.pone.0174860).

[25] C. Berkland, M. King, A. Cox, K. K. Kim, D. W. Pack (2002) Precise control of PLG microsphere size provides enhanced control of drug release, J. Controlled Release, 82 (1), 137-147.

[26] R. E. Eliaz, J. Kost (2000) Characterization of PLGA injectable implant delivery system for the controlled release of proteins, J. Biomed. Mater. Res., 50 (3), 388-396.

[27] H. K. Makadia, S.J.Siegel (2011) Poly Lactic-coGlycolic Acid (PLGA) as Biodegradable Controlled Drug Delivery Carrier, Polymers, 3 (3), 1377-1397.

[28] J. Fernández, A. Etxeberria, J.-R. Sarasua (2012) Synthesis, structure and properties of poly $(\mathrm{L}-$ lactide-co- $\varepsilon$-caprolactone) statistical copolymers, Journal of the Mechanical Behavior of Biomedical Materials, 9, 100-112.

[29] M.Ryner, A.-Ch.Albertsson (2002) Resorbable and Highly Elastic Block Copolymers from 1,5Dioxepan-2-one and I-Lactide with Controlled Tensile Properties and Hydrophilicity, Biomacromolecules, 3 (3), 601-608.

[30] R. Langer, J. P. Vacanti (1993) Tissue engineering, Science, 260 (5110) 920-926.

[31] T. Lu, Y. Li, T. Chen (2013) Techniques for fabrication and construction of three-dimensional scaffolds for tissue engineering, International Journal of Nanomedicine, 8 (1), 337-350.

[32] B. Dhandayuthapani, Y. Yoshida, T. Maekawa, D. S. Kumar (2011) Polymeric Scaffolds in Tissue Engineering Application: A Review, International Journal of Polymer Science, 1-19 (https://www. hindawi.com/journals/ijps/2011/290602/).

[33] B.P.Chan, K.W. Leong (2008) Scaffolding in tissue engineering: general approaches and tissuespecific considerations, Eur Spine J., 17(4), 467479.

[34] T.Kouya, S.-I.Tada, H.Minbu, Y.Nakajima, M. Horimizu, T.Kawase, D.R. Lloyd, T.Tanaka (2013) Microporous membranes of PLLA/PCL blends for periosteal tissue scaffold, Mater. Lett., 95, 103106.

[35] D.A.Olson, S.E.Gratton, J.M.DeSimone, V.V Sheares (2006) Amorphous linear aliphatic polyesters for the facile preparation of tunable rapidly degrading elastomeric devices and delivery vectors, J. Am. Chem. Soc., 128(41), 13625-33.

[36] L.Brito, S.Little, R.Langer, M.Amiji (2008) Poly(beta-amino ester) and cationic phospholipidbased lipopolyplexes for gene delivery and transfection in human aortic endothelial and smooth muscle cells, Biomacromolecules, 9 (4), 11791187. 
[37] H.-Y. Mi, M.R.Salick, X. Jing, B.R.Jacques, W.C Crone, X.-F.Peng, L.-S.Turng (2013) Characterization of thermoplastic polyurethane/ polylactic acid (TPU/PLA) tissue engineering scaffolds fabricated by microcellular injection molding, Mater. Sci. Eng. C Matter. Biol. Appl., 33 (8), 4767-4776.

[38] T.Govindarajan, R.Shandas (2014) A Survey of Surface Modification Techniques for NextGeneration Shape Memory Polymer Stent Devices, Polymers, 6 (9), 2309-2331.

[39] M.Tallawi, E.Rosellini, N.Barbani, M.G.Cascone, R Rai, G. Saint-Pierre, A. R. Boccaccini (2015) Strategies for the chemical and biological functionalization of scaffolds for cardiac tissue engineering: a review, J. R. Soc. Interface 12 (108) 20150254, http://dx.doi.org/10.1098/rsif.2015.0254.

[40] N.Kayaman-Apohan, O.Karal-Yilmaz, K.Baysal, B. Baysal (2001) Poly(DL-lactic acid)/triblock PCLPDMS-PCL copolymers: Synthesis, characterization and demonstration of their cell growth effects in vitro, Polymer 42 (9), 4109-4116.

[41] A.Porjazoska, N.Kayaman-Apohan, O.KaralYilmaz, M.Cvetkovska, K.Baysal, B.Baysal (2002) Synthesis and characterization of glycolide, Llactide, and PDMS-based terpolymers as a support for cell cultures, J. Biomater. Sci. Polymer Edn., 13 (10), 1119-1134.

[42] S.I.A.Razak, N.Sharif, W.Rahman (2012) Biodegradable polymers and their bone applications: A review, Int. J. Basic Appl. Sci., 12 (1), 31-49.

[43] E. Nejati, H.Mirzadeh, M.Zandi (2008) Synthesis and characterization of nano-hydroxyapatite rods/poly (L-lactide acid) composite scaffolds for bone tissue engineering. Composites Part A: Applied Science and Manufacturing, 39 (10), 15891596.

[44] F. Pu, N. P. Rhodes, Y. Bayon, R. Chen, G. Brans, R. Benne, J. A. Hunt (2010) The use of flow perfusion culture and subcutaneous implantation with fibroblast-seeded PLLA-collagen 3D scaffolds for abdominal wall repair, Biomaterials, 31, 43304340.

[45] Ch.Yan, J. Zhang, Y. Lv, J. Yu, J. Wu, J. Zhang, J. $\mathrm{He}$ (2009) Thermoplastic Cellulose-graft-poly(Ilactide) Copolymers Homogeneously Synthesized in an Ionic Liquid with 4-Dimethylaminopyridine Catalyst, Biomacromolecules, 10 (8), 2013-2018.

[46] S. M. Cho, S. Y. Kim, Y.M. Lee, Y. K. Sung, Ch. S. Cho (1999) Synthesis, properties, and permeation of solutes through hydrogels based on poly(ethylene glycol)-co-poly(lactones)di-acrylate macromers and chitosan, J. Appl. Polym. Sci, 73 (11) 2151-2158.

[47] D.Wang, X.-De Feng (1997) Synthesis of Poly(glycolic acid-alt-I-aspartic acid) from a Morpholine-2,5-dione Derivative, Macromolecules, 30 (19), 5688-5692.

[48] Y.Feng, J.Lu, M. Behl, A.Lendlein (2010) Progress in Depsipeptide-Based Biomaterials, Macromol. Biosci., 10 (9) 1008-1021.

[49] X.Deng, J.Yao, M.Yuan, X.Li, C.Xiong (2000) Polymerization of lactides and lactones, 12.
Synthesis of poly[(glycolic acid)-alt-(L-glutamic acid)] and poly\{(lactic acid)-co-[(glycolic acid)-alt(L-glutamic acid)]\}. Macromol. Chem. Phys., 201 (17), 2371-2376.

[50] O.K.Yilmaz, N. K.Apohan, Z.Misirli, K.Baysal, B. M. Baysal (2006) Synthesis and characterization of poly(L-lactic acid-co-ethylene oxide-co-aspartic acid) and its interaction with cells, J, Mater, Sci.: Mater. Med., 17(3), 213-227.

[51] H. Shinoda, Y. Asou, A. Suetsugu, K. Tanaka (2003) Synthesis and characterization of amphiphilic biodegradable copolymer, poly(aspartic acid-co-lactic acid), Macromol. Biosci., 3 (1) 34-43.

[52] R.E.Guldberg (2009) Spatiotemporal delivery strategies for promoting musculoskeletal tissue regeneration, J. Bone Miner. Res., 24 (9) 1507-1511.

[53] N.Monteiro, A.Martins, R.L.Reis, N.M.Neves (2015) Nanoparticle-based bioactive agent release systems for bone and cartilage tissue engineering, Regenerative Therapy, 1, 109-118.

[54] S. Minardi, F. Taraballi, L. Pandolfi, E. Tasciotti (2016) Patterning biomaterials for the spatiotemporal delivery of bioactive molecules, Front. Bioeng. Biotechnol., 4, 1-7.

[55] S. Minardi, B. Corradetti, F. Taraballi, J. H. Byun, F. Cabrera, X. Liu, M. Ferrari, B. K. Weiner, E. Tasciotti (2016) IL-4 release from a biomimetic scaffold for the temporally controlled modulation of macrophage response, Ann. Biomed. Eng., 44 (6), 2008-2019.

[56] W.Yuan, Z.Liu (2012) Controlled-release and preserved bioactivity of proteins from (selfassembled) core-shell double-walled microspheres, Int. J. Nanomed., 7, 257-270.

[57] J.C.Hoffmann, J.L.West (2010) Three-dimensional photolithographic patterning of multiple bioactive ligands in poly (ethylene glycol) hydrogels, Soft Matter, 6 (20) 5056-5063.

[58] C.Spadaccio, F.Nappi, F.De Marco, P.Sedati, Ch. Taffon, A.Nenna, A.Crescenzi, M.Chello, M. Trombetta, I.Gambardella, A.Rainer (2017) Implantation of a poly-L-lactide GCSF-functionalized scaffold in a model of chronic myocardial infarction, J. Cardiovasc. Trans. Res., 10, 47-65.

[59] L.Pandolfi, S.Minardi, F.Taraballi, X. Liu, M. Ferrari, E.Tasciotti (2016) Composite microspherefunctionalized scaffold for the controlled release of small molecules in tissue engineering, Journal of Tissue Engineering, 7, 1-11.

[60] W.K.Hsu, M.S.Nickoli, J.C.Wang, J.R.Lieberman, H.S.An, S.T.Yoon, J.A.Youssef, D.S. Brodke, C. M. McCullough (2012) Improving the clinical evidence of bone graft substitute technology in lumbar spine surgery, Global Spine J. 2 (4) 239-248.

[61] L.Jin, T.Wang, Z.-Q.Feng, M.Zhu, M.K.Leach, Y.I.Naime, Q.Jianga (2012) Fabrication and characterization of a novel fluffy polypyrrole fibrous scaffold designed for 3D cell culture, J. Mater. Chem., 22 (35) 18321-18326.

[62] A.Gelmi, M.K.Ljunggren, M.Rafatbc, E.W.H. Jagera (2014) Influence of conductive polymer doping on the viability of cardiac progenitor cells, J. Mater. Chem. B, 2, 3860-3867. 
[63] J.H.Collier, J.P.Camp, T.W.Hudson, C.E.Schmidt (1999) Synthesis and characterization of polypyrrole - hyaluronic acid composite biomaterials for tissue engineering applications, J. Biomed. Mater. Res., 50 (4), 574-584.

[64] J.S.Moreno, S.Panero, M. Artico, P. Filippini (2008) Synthesis and characterization of new electroactive polypyrrole - chondroitin sulphate A substrates, Bioelectrochemistry, 72 (1), 3-9.

[65] J.S. Moreno, S. Panero, S. Materazzi, A. Martinelli, M.G.Sabbieti, D.Agas, G.Materazzi (2009) Polypyrrole-polysaccharide thin films characteristics: electrosynthesis and biological properties, J. Biomed. Mater. Res., Part A, 88 (3), 832-840.

[66] K.J.Gilmore, M.Kita, Y.Han, A.Gelmi, M. J.Higgins, S. E.Moulton, G. M.Clark, R. Kapsa, G. G.Wallace (2009) Skeletal muscle cell proliferation and differentiation on polypyrrole substrates doped with extracellular matrix components, Biomaterials, 30 (29), 5292-5304.

[67] K.Svennersten, M.Berggren, A.Richter-Dahlfors, E. W.H.Jager, (2011) Mechanical stimulation of epithelial cells using polypyrrole microactuators, Lab Chip, 11 (19), 3287-3293.

[68] B.C.Thompson, S.E.Moulton, R.T.Richardson, G. G.Wallace (2011) Effect of the dopant anion in polypyrrole on nerve growth and release of a neurotrophic protein, Biomaterials, 32 (15) 38223831.

[69] G.Shi, M.Rouabhia, Zh.Wang, L.H.Dao, Z.Zhang (2004) A novel electrically conductive and biodegradable composite made of polypyrrole nanoparticles and polylactide, Biomaterials, 25 (13), 2477-2488.

[70] S.B.Manjunatha, D.P.Biradar, Y.R.Aladakatti (2016) Nanotechnology and its applications in agriculture: A review, J. Farm. Sci., 29 (1), 1-13.

[71] L. B. Peppas (1993), Controlled release in the food and cosmetics industries, Polymeric Delivery Systems, 520 (3) 42-52.

[72] K.E.Uhrich, S.M.Cannizzaro, R.S. Langer, K.M. Shakesheff (1999) Polymeric Systems for Controlled Drug Release, Chem. Rev., 99 (11), 3181-3198.

[73] B.Jeong, Y.H. Bae, D.S.Lee, S.W.Kim (1997) Biodegradable block copolymers as injectable drug-delivery systems, Nature, 388, 860-862.

[74] E.P.Holowka, S.K.Bhatia (2014) ControlledRelease Systems, book Drug Delivery: Materials Design and Clinical, Springer, New York, 7-62.

[75] R. M. Mainardes, M. C. Urban, P. O. Cinto, M. V. Chaud, R. C. Evangelista, M. P. Gremião (2006) Liposomes and micro/nanoparticles as colloidal carriers for nasal drug delivery, Curr. Drug. Deliv., 3 (3), 275-285.

[76] M.Komatsu, K. Tagawa, M. Kawata, S. Goto (1983) Biopharmaceutical evaluation of gelatine microcapsules of sulphonamides, Chem. Pharm. Bull., 31 (1), 262-268.

[77] W. B. Liechty, D. R. Kryscio, B. V. Slaughter, N. A Peppas (2010) Polymers for Drug Delivery
Systems, Annu. Rev. Chem. Biomol. Eng., 1, 149 173.

[78] A.Porjazoska, K.Goracinova, K.Mladenovska, M. Glavaš, M. Simonovska, E. I. Janjević, M. Cvetkovska (2004) Poly(lactide-co-glycolide) microparticles as systems for controlled release of proteins: preparation and characterization, Acta Pharmaceutica, 54 (3), 215-229.

[79] S.P.Li, C.R.Kowalski, K.M. Feld, W. M. Grim (1988) Recent advances in microencapsulation technology and equipment, Drug Delivery Ind. Pharm., 14 (23), 353-376.

[80] P. K. Gupta, C.T.Hung (1989) Effect of carrier dose on the multiple tissue disposition of doxorubicin hydrochloride administered via magnetic albumin microspheres in rats, J. Pharm. Sci., 78 (9), 745748.

[81] J.R.Joshi, R.P.Patel (2012) Role of biodegradable Polymers in drug delivery. International Journal of Current Pharmaceutical Research, 4 (2), 74-81.

[82] B. L. Montalvo-Ortiz, B. Sosa, K. Griebenow (2012) Improved enzyme activity and stability in polymer microspheres by encapsulation of protein nanospheres, AAPS Pharm. Sci. Tech., 13 (2), 632-636.

[83] S.D'Souza, J.A.Faraj, P.P.DeLuca (2015) Unstirred water layer effects on biodegradable microspheres, Advances in Pharmaceutics, Article ID 823476, https://www.hindawi.com/archive/ 2015/ 823476/.

[84] D.J.Kirby, I.Rosenkrands, E.M.Agger, P. Andersen, A.G.Coombes, Y.Perrie (2008) PLGA microspheres for the delivery of a novel subunit TB vaccine, J Drug Target., 16 (4), 282-293.

[85] K. R. Parida, S. K. Panda, P. Ravanan, H. Roy, M. Manickam, P. Talwar (2013) Microparticles based drug delivery systems: Preparation and application in cancer therapeutics, International Archive of Applied Sciences and Technology, 4 (3), 68-75.

[86] M. S. Sabel, J. Skitzki, L. Stoolman, N. K. Egilmez, E. Mathiowitz, N. Bailey, W. J. Chang, A. E. Chang (2004) Intratumoral IL-12 and TNF-alpha-loaded microspheres lead to regression of breast cancer and systemic antitumor immunity, Ann. Surg. Oncol., 11 (2), 147-156.

[87] V.R.Sinha, K.Bansal, R.Kaushik, R.Kumria, A. Trehan (2004) Poly-caprolactone microspheres and nanospheres, International Journal of Pharmaceutics, 278 (1), 1-23.

[88] P.G.Shukla, B. Kalidhass, A. Shah, D. V. Palashkar (2002) Preparation and characterization of microcapsules of water soluble pesticide monocrotophs using polyurethane as carrier material, J. Microencapsul.,19 (3), 293-304.

[89] D.S.Kohane (2007) Microparticles and nanoparticles for drug delivery, Biotechnology and Bioengineering, 96 (2), 203-209.

[90] V.Labhasetwar, C.Song, R.J.Levy (1997) Nanoparticle drug delivery system for restenosis. Advanced Drug Delivery Reviews, 24 (1), 63-85.

[91] A.Mahapatro, D.K.Singh (2011) Biodegradable nanoparticles are excellent vehicle for site directed in-vivo delivery of drugs and vaccines, $J$. Nanobiotechnology, 9, 1-11. 
[92] M.L.Hans, A.M.Lowman (2002) Biodegradable nanoparticles for drug delivery and targeting, Current Opinion in Solid State and Materials Science, 6(4), 319-327.

[93] V.P.Torchilin, V.S.Trubetskoy (1995) Which polymers can make nanoparticulate drug carriers long-circulating?, Advanced Drug Delivery Reviews, 16 (2-3),141-155.

[94] S. Stolnik, L. Illum, S. S. Davis (1995) Long circulating microparticulate drug carriers, Advanced Drug Delivery Reviews, 16 (2-3), 195-214

[95] R. Gref, M. Lück, P. Quellec, M. Marchand, E. Dellacherie, S. Harnisch, T. Blunk, R. H. Müller (2000) 'Stealth' corona-core nanoparticles surface modified by polyethylene glycol (PEG): influences of the corona (PEG chain length and surface density) and of the core composition on phagocytic uptake and plasma protein adsorption, Colloids and Surfaces B: Biointerfaces, 18 (3-4), 301-313.

[96] K. Park, S. Lee, E.Kang, K.Kim, K. Choi, I. C. Kwon (2009) New Generation of Multifunctional Nanoparticles for Cancer Imaging and Therapy, Advanced Functional Materials, 19 (10), 15531566.

[97] M.M.Alvarez, J.Aizenberg, M.Analoui, A.M. Andrews, G. Bisker, E. S. Boyden, R. D. Kamm, J. M. Karp, D.J.Mooney, R. Oklu, D. Peer, M. Stolzoff, M.S.Strano, G.Trujillo-de Santiago, Th. J. Webster, P. S. Weiss, A. Khademhosseini (2017) ACS Nano, in press,

[98] http://pubs.acs.org/doi/abs/10.1021/acsnano.7b014 93

[99] A.Porjazoska, Ph.Dimitrov, I.Dimitrov, M. Cvetkovska, Ch. Tsvetanov (2004) Synthesis and aqueous solution properties of functionalized and thermoresponsive poly(D,L-lactide)/polyether block copolymers, Macromolecular Symposia, 210 (1), 427-436.

[100] Ph.Dimitrov, A.Porjazoska, Ch.Novakov, M. Cvetkovska, Ch. B. Tsvetanov, (2005) Functionailzed micells from new $A B C$ polyglycidolpoly(ethylene oxide)-poly(D,L-lactide) terpolymers, Polymer, 46 (18), 6820-6828.

[101] S. S. Kulthe, Y. M. Choudhari, N. N. Inamdar, V. Mourya (2012) Polymeric micelles: authoritative aspects for drug delivery, Designed Monomers and Polymers 15 (5), 465-521.

[102] S. Cammas, K. Suzuki, C. Sone, Y. Sakurai, K. Kataoka, T. Okano (1997) Thermo-responsive polymer nanoparticles with a core-shell micelle structure as site-specific drug carriers, Journal of Controlled Release, 48 (2-3) 157-164.

[103] C.Wu, A.Ying, S.Ren (2013) Fabrication of polymeric micelles with core-shell-corona structure for applications in controlled drug release, Colloid Polym. Sci., 291 (4), 827-834.

[104] P. Alexandridis, J. F.Holzwarth, T. A. Hatton (1994) Micellization of Poly(ethylene oxide)Poly(propylene oxide)-Poly(ethylene oxide) Triblock Copolymers in Aqueous Solutions: Thermodynamics of Copolymer Association, Macromolecules, 27 (9), 2414-2425.
[105] R. Zh. Xiao, Zh. Wu Zeng, G. L. Zhou, J. J. Wang, F. Zh. Li, A. M. Wang (2010) Recent advances in PEG-PLA block copolymer nanoparticles, International Journal of Nanomedicine, 5, 1057-1065.

[106] M.Ch.Jones, J.Ch. Leroux (1999) Polymeric micelles - a new generation of colloidal drug carriers, Eur. J. Pharm. Biopharm., 48 (2), 101-111.

[107] K.E.Lee, B.K. Kim, S. H. Yuk (2002) Biodegradable Polymeric Nanospheres Formed by TemperatureInduced Phase Transition in a Mixture of Poly(lactide-co-glycolide) and Poly(ethylene oxide)-Poly(propylene oxide)-Poly(ethylene oxide) Triblock Copolymer, Biomacromolecules, 3 (5), 1115-1119.

[108] Y. Zhang, R.-Xi Zhuo (2005) Synthesis and in vitro drug release behavior of amphiphilic triblock copolymer nanoparticles based on poly (ethylene glycol) and polycaprolactone, Biomaterials, 26 (33), 6736-6742.

[109] A.Eatemadi, H.T.Aiyelabegan, B.Nagahdari, B. Rajeian, N.Zarghami (2016) Synthesis and Characterization of Chrysin-loaded PCL-PEG-PCL nanoparticle and its effect on breast cancer cell line, Biomedicine \& Pharmacotherapy, 84, 19151922

[110] X.Y. Xiong, K. C. Tam, L. H. Gan, (2003) Synthesis and aggregation behaviour of Pluronic F127/poly(lactic acid) block copolymers in aqueous solutions, Macromolecules, 36 (26), 9979-9985.

[111] Y. Ma, X. Jiang, R. Zhuo (2013) Biodegradable and thermosensitive micelles of amphiphilic polyaspartamide derivatives containing aromatic groups for drug delivery, Inc. J. Polym. Sci., Part A: Polym. Chem., 51 (18), 3917-3924.

[112] F.Bahadori, A.Dag, H.Durmaz, N.Cakir, H. Onyuksel, U.Tunca, G.Topcu, G.Hizal (2014) Synthesis and Characterization of Biodegradable Amphiphilic Star and Y-Shaped Block Copolymers as Potential Carriers for Vinorelbine Polymers, 6 (1), 214-242.

[113] Zh. Xu, Sh.Liu, Y.Kang, M.Wang (2015) Glutathione-responsive polymeric micelles formed by a biodegradable amphiphilic triblock copolymer for anticancer drug delivery and controlled release, ACS Biomater. Sci. Eng., 1 (7), 585-592.

[114] Y. Zhang, Y. Huang, S. Li (2016) Polymeric Micelles: Nanocarriers for Cancer-Targeted Drug Delivery, AAPS Pharm. Sci. Tech, 15 (4), 862-871;

[115] N.Nishiyama, Y.Matsumura, K.Kataoka (2016) Development of polymeric micelles for targeting intractable cancers, Cancer Sci. 107 (7), 867-874.

[116] J.H.Jeong, S.W.Kim, T.G.Park (2003) Novel Intracellular Delivery System of Antisense Oligonucleotide by Self-Assembled Hybrid Micelles Composed of DNA/PEG Conjugate and Cationic Fusogenic Peptide Department of Biological Sciences, Bioconjugate Chem., 14 (2), 473-479.

[117] V.P.Torchilin (2002) PEG-based micelles as carriers of contrast agents for different imaging modalities, Advanced Drug Delivery Reviews, 54 (2) $235-252$.

[118] A.Kumari, S.K.Yadav, S.C.Yadav (2010) Biodegradable polymeric nanoparticles based drug 
delivery systems. Colloids and Surfaces B: Biointerfaces, 75 (1),1-18.

[119] A. Mahapatro, D. M.Johnson, D.N.Patel, M.D. Feldman, A. A. Ayon, C.M. Agrawal (2008) Drug Delivery from Therapeutic Self-Assembled Monolayers (T-SAMs) on 316L Stainless Steel, Current Topics in Medicinal Chemistry, 8 (4), 281-289.

[120] A.Gopferich (1996) Polymer degradation and erosion: mechanisms and applications, Biomaterials, 17 (2), 103-114.

[121] C.Engineer, J. Parkish, A. Raval, (2011) Review on Hydrolytic Degradation Behavior of Biodagradable Polymers from Controlled Drug Delivery Systems,
Trends in Biomaterials and Artificial Organs, 25 (2), 79-85.

[122] A.Gopferich (1997) Polymer bulk erosion, Macromolecules, 30 (9), 2598-2604.

[123] A.Gopferich, R. Langer (1993) Modeling of polymer erosion, Macromolecules, 26 (16), 4105-4112.

[124] S.Hurell, R.E.Cameron (2001) Polygycolide:degradation and drug release. Part I. Changes in morphology during degradation, J. Mater. Sci.Mater. Med., 12 (9), 811-816.

[125] C.S.Proikakis, N.J.Mamouzelos (2006) Swelling and hydrolytic degradation of poly( d, I-lactic acid) in aqueous solutions, Polym. Degrad. Stab, 91 (3), 614-619.

\title{
IZVOD
}

\section{BIORAZGRADLJIVI POLIMERI POGODNI ZA INŽENJERSTVO TKIVA I SISTEMA ZA DOSTAVU LEKOVA}

\begin{abstract}
Biorazgradivi polimeri za medicinsku i farmaceutsku primenu su u fokusu naučnog interesovanja u poslednje dve decenije. Između ostalih karakteristika, osobine poput biokompatibilnosti, podržavanje proliferacije ćelija i biorazgradljivost smatraju se kao ključne u izradu podloga u inženjerstvu tkiva i sistema za kontroliranu dostavu lekova. Polimeri na bazi poliestera, polietera, polianhidrida, poli(etar estera), poli(orto estera), poli(amino kiselina) su veoma značajni za primenu u medicini i farmaciji. Porozne polimerne matrice u inženjeringu tkiva podstiču rast ćelija, omogućavajući istovremenu razmenu nutrijenata i metabolita. Sistemi za dostavu lekarstava, gde je aktivna komponenta dispergovana / rastvorena u polimernoj matrici, imaju ulogu rezervoara, dok nosioci lekova su sistemi u kojima je aktivna supstanca vezana hemijski za polimernu matricu. Poseban interes mnogih istraživača privlače sistemi u kojima degradacija polimernih matrica je krucijalna u određivanju brzine kojom se lek oslobađa. Biorazgradljivi sistemi sa nanodimenzijama, koji imaju ulogu uređaja za kontolirano oslobođenje ili selektivno nasočivanje aktivne komponente privlače značajnu pažnju.

Ovaj rad predstavlja kratki pregled biorazgradljivh polimera, njihova svojstva značajna za primenu u medicini, sa posebnim naglaskom na njihovu hidrolitičku degradaciju, što bi poslužilo kako osnova za dalja istraživanja u ovom području.
\end{abstract}

Ključne reči: biorazgradljivi polimeri, inženjering tkiva, sistemi za dostavu lekova.

\section{Pregledni rad}

Rad primljen: 15. 06. 2017.

Rad prihvaćen: 10. 07. 2017.

Rad je dostupan na sajtu: www.idk.org.rs/casopis

(c) 2017 Authors. Published by Inženjersko društvo za koroziju. This article is an open access article distributed under the terms and conditions of the Creative Commons Attribution 4.0 International license (https://creativecommons.org/licenses/by/4.0/) 